\title{
Paradidactic infrastructure for sharing and documenting mathematics teacher knowledge: a case study of "practice research" in Japan
}

\author{
Takeshi Miyakawa $^{1}$ (D) Carl Winsløw $^{2}$ (D)
}

Published online: 5 December 2017

(C) The Author(s) 2017. This article is an open access publication

\begin{abstract}
Japanese lesson study was introduced to the West in the late 1990s. Certain widely disseminated publications and classroom videos, and also reports on international surveys of students achievement, led many to consider that Japanese mathematics teaching is highly creative and effective, with lesson study as a main explanatory factor. As a result, substantial efforts have been deployed in many countries to engage mathematics teachers in lesson study. In this paper, we argue that lesson study is but one element of a comprehensive Japanese "infrastructure" for developing teacher knowledge, both personal and shared, and that the functions and workings of any particular element in this infrastructure cannot be fully understood when viewed in isolation. In this paper, we offer a systemic (institutional) analysis of how these "infrastructure" elements interact in crucial ways. Specifically we study two episodes where a teacher's "practice research" is clearly motivated and supported by other infrastructural conditions, such as the possibility to present the outcomes at a regional teacher conference, and in a publication. Moreover, a central prerequisite for the creative part of "lesson planning" is a much more limited activity: the patient study and discussion of mathematical tasks and materials. This activity is also crucially supported by elements of the infrastructure.
\end{abstract}

Keywords Japanese lesson study · Paradidactic infrastructure · Praxeology · Anthropological theory of the didactic

Alphabetical order. Takeshi Miyakawa and Carl Winsløw have contributed equally to this paper.

Carl Winsløw

winslow@ind.ku.dk

1 Department of Mathematics, Joetsu University of Education, 1 Yamayashiki-machi, Joetsu 943-8512, Japan

2 Department of Science Education, University of Copenhagen, Øster Voldgade 3, 1350 Copenhagen K, Denmark 


\section{Introduction}

International comparative studies have suggested intriguing differences across nations when it comes to students' basic competences in mathematics (e.g. de Lange 2007) and practices of mathematics teaching (e.g. Knipping 2003). In fact, early efforts to systematically study and compare classroom practices across nations and cultures, such as the TIMSS video study (e.g. Stigler and Hiebert 1999), were spurred by the differences found in students' response to international surveys like TIMSS. This led to a growing interest in the cultural and institutional conditions for mathematics teachers' practice and knowledge in East Asia, and more broadly to research seeking to make sense of what Stigler and Hiebert (op. cit.) called "the teaching gap", particularly between Western and East Asian countries (cf. Leung et al. 2006). In many countries, reforms and debates related to teacher education also renew and strengthen researchers' interest in the nature and development of mathematics teachers' professional practices and knowledge, and have led to numerous theoretical categorizations of what mathematics teachers know, or should know (Blömeke and Delaney 2012). At the same time, the focus on teachers' practices also begins to extend to in-depth research on how teachers work outside of the classroom, as they study and prepare for teaching (e.g. Gueudet and Trouche 2009).

Our own work in this field is motivated by a concern about two crucial links:

- the link between what teachers do (inside and outside the classroom) and the professional knowledge they develop and share about these practices-these compounds of practice and knowledge are modelled as didactic and paradidactic praxeologies (cf. Chevallard 1999; Winsløw 2011; Miyakawa and Winsløw 2013) as will be further explained in this paper;

- the link between these praxeologies and their institutional and cultural conditions, such as available resources, modalities of teachers' collaboration, channels for sharing didactic praxeologies.

In this paper, we conduct a theoretical and empirical study of these links with a special focus on the conditions which exist in Japan, when it comes to develop, share and implement didactic knowledge. These particular conditions have often been alluded to in the literature, especially in descriptions of Japanese lesson study:

... this countrywide lesson study process generates practitioner knowledge but within a system containing features identified earlier as essential for transforming such knowledge into a professional knowledge base (Hiebert et al. 2002, p. 10)

Furthermore, innovative and motivated groups sometimes pursue publishing either a monograph or articles about their lesson study. These writings (....) are often distributed nationwide through major bookstores. (Fernandez and Yoshida 2004, p. 179).

Certainly, a main source of interest with Japanese lesson study has been the affordances of this work format for both using and producing didactic knowledge shared by a wider community of teachers ("professional knowledge" in the sense of Hiebert et al. 2002), made possible by the existence in Japan of a wide variety of publication channels. Lewis et al. (2006) suggested that knowledge gained in contexts like lesson study is validated inductively through a "local proof route", as opposed to the top-down approach of some 
types of "what works" research found in the West. But a systematic and detailed study of the ways in which "local knowledge" becomes more widely shared does not seem to exist and it is one of the purposes of this paper to fill that gap.

More broadly, this paper aims to shed light on the conditions or "features" which allow Japanese mathematics teachers to represent, communicate and develop didactic knowledge (including also knowledge about mathematics!), from the local school to the national level. The most well known of these "features" are those directly related to observation of experimental didactic practice, such as lesson study (e.g. Miyakawa and Winsløw 2009) and open lessons (Miyakawa and Winsløw 2013). But even these activities are based on documents and other resources whose creation and dissemination rely on an "infrastructure" for professional exchange and publication of mathematics teacher knowledge that goes far beyond the "real-time" observation and discussion of lessons.

The present paper aims to describe and explore this "infrastructure" more systematically, by:

- analysing a case study (in two episodes) of how didactic practice becomes theorized and eventually published, beginning with discussing some first ideas for a so-called practice research (see below) in the setting of a local mathematics teacher association, and culminating in a paper for a regional teacher congress;

- for and through this case study, present a model for such analyses and their wider perspectives, by drawing on the anthropological theory of the didactic and in particular our previous work on paradidactic infrastructure.

Here, "practice research" (jissen kenky $\bar{u}$ ) is a broader term that denotes the study and research on teaching practices, carried out mainly by an individual teacher or a group of teachers for the purpose of improving their teaching practices. It usually includes development of teaching materials and/or teaching methods, task design, teaching experiments, analyses, etc., like in a lesson study which can be seen as a specific kind of practice research. The results of practice research are often published and shared at different institutional levels in the form of a practice research report (further details on this later).

\section{Theoretical Framework and Research Questions}

Our study is based on the anthropological theory of the didactic (ATD). The need for theorizing is quite obvious: our object of research involves not only the well-known intricacy of "mathematics teacher knowledge" but also a complex network of institutional levels and venues for its development and dissemination, along with more general cultural features of Japanese society. While "lesson study" has been widely described and disseminated in the West, it remains unclear to the reader of these descriptions in what sense - and how-this school-based activity can lead to professional knowledge about mathematics teaching which is public, storable, shareable, verifiable and improvable, to use the terms of Hiebert et al. (2002). Some research refers to the wider context of Japanese teachers' practices related to the lesson study and notes how lesson study is affected by certain elements of the context (Lewis and Tsuchida 1997; Lewis 2014). Our aim here is to pursue this point systematically, with a specific theoretical framework, and with lesson study as just one possible format for developing mathematics teacher knowledge. As usual in scientific research, the role of a theoretical framework is to make our assumptions, reasonings, research objects and research questions precise and explicit. It is particularly 
important when the research objects include such complex and culturally embedded phenomena as teacher knowledge, and "settings" for developing it. We briefly recall the main notions of ATD (cf. Chevallard 1999, 2006) which goes into the definition and study of "paradidactic infrastructure". In ATD, human knowledge is modelled in terms of praxeologies which, as the word suggests, consist of two main parts: praxis (practical knowledge, "know-how") and logos (explicit knowledge about the praxis, including explanations and justifications of specific techniques, and also more theoretical discourse). Praxis consists of types of tasks and techniques used to solve them; logos consist of technology (discourse about the techniques) and theory (abstract discourse which clarifies, unifies or justifies the technology).

Mathematics teaching is about disseminating mathematical praxeologies where the praxis involves mathematical tasks and techniques, for instance for solving linear equations, while the logos block involves explanations of techniques, definitions of terms, rules, theorems, proofs, and so on. However, teaching mathematics draws on didactic praxeologies: praxis and logos related to teach some specific mathematical praxeology. We note that some parts of didactic praxis and logos may be more generic (i.e. independent of specific mathematics), especially at the theoretical level of logos.

Mathematics teacher knowledge consists thus, foremost, of didactic praxeologies, but these are naturally inseparable from the mathematical praxeologies whose teaching they bear on, and can also be enriched (especially at the logos level) by related mathematical praxeologies. But it still makes sense to consider the core of mathematics teachers' knowledge as didactic.

The exercise and development of teachers' mathematical and didactic praxeologies depend on a number of conditions and constraints which, at a given time, are more or less given and which are crucially related to the institutional system in which the teacher works. Among these conditions and constraints are those which directly bear on the teacher's activity in the classroom and, more generally, on teaching and supervision of studentsfollowing Chevallard (2009), we call the totality of these a didactic infrastructure. The notion is admittedly abstract, but just as with infrastructures in more common contexts (such as for transportation of people within a city) the point is the systemic point of view, to consider a multitude of apparently unrelated factors as a coherent whole which conditions and constrains a particular set of praxeologies, without determining them entirely. Teacher's praxeologies, as they unfold and possibly develop during teaching practice, are both constrained and resourced by a system of given factors-from class period length and technological devices to exercise collections and syllabi. The "infrastructure of the classroom" thus involves both elements which are generic to all teachers of a given school and some which are specific to the teaching of mathematics and thus to the development of students' mathematical praxeologies.

Teachers do not only exercise and develop their didactic and mathematical praxeologies in the classroom or when otherwise interacting with students. They prepare their teaching, they often participate in various professional meetings and courses, and so on. We call these "teaching-related" practices paradidactic-they concern, but are not themselves, teaching. How and in what forms these practices occur for a given teacher depend, just as his teaching, on a given system of conditions and constraints, the totality of which we call the paradidactic infrastructure in which the teacher works when he is not teaching. The paradidactic and the didactic infrastructures may share some elements, such as textbooks which are often crucial to teachers' preparation of teaching, but a paradidactic infrastructure may also involve institutionally given frameworks such as the examples of lesson 
study and open lessons, as further explored by Miyakawa and Winsløw (2013) and Rasmussen (2016).

In particular, lesson study in Japan is often described as if it were an independent format of paradidactic practice; we claim that it can only be fully understood when considered as part of a wider paradidactic infrastructure, the paradidactic infrastructure available for primary and secondary level mathematics teachers in Japan (we abbreviate this JPI, for short).

Our general research questions are then:

RQ1 What elements of JPI allow Japanese mathematics teachers to access, produce and disseminate didactic and mathematical praxeologies?

RQ2 How do these elements depend on each other, and shape the teachers' praxeologies?

So far, the international research literature has little concrete to offer for the first question besides extensive accounts and analyses of the practice of lesson study. Some of the early accounts mention a wider "system" of professional development formats in Japan (i.e. Lewis and Tsuchida 1997; Lewis 2014; Isoda et al. 2007), but this "system" has not, to our knowledge, been described beyond the stage of giving examples. Indeed, most previous research focuses on one element of JPI, "lesson study", and to some extent on how the transplanted lesson study format turns out to be compatible with the paradidactic infrastructure in other countries such as the USA. Thus, in relation to previous research, two points of this paper are to exhibit and analyse other elements of JPI which may be as inspiring for development in other countries, and to show that lesson study in Japan depends crucially on some of these other elements.

The two research questions can hardly be approached empirically in other ways than through a qualitative study of selected examples or cases. We now turn to methodological considerations about the study of JPI and in particular the above research questions.

\section{Methodology}

The systemic definition of paradidactic infrastructures is rather new (Winsløw 2011), and there are no firmly established methods to investigate questions about them, let alone represent them as a whole. As for the whole or totality of the JPI, we do not know what could be analogous to a more or less detailed map of city transportation infrastructure. In investigations of specific elements, such as in-service courses or lesson study, the literature offers case studies based on observation data, interviews with the participants and sometimes also analysis of the documents or materials they work with (cf. e.g. Gueudet et al. 2012). Interview data may, in particular, give information of wider systemic features of a paradidactic infrastructure and are then essentially based on the respondents' personal view of what are important conditions and constraints for their paradidactic practice.

We have chosen, in this paper, to provide first a bold and partial answer to RQ1 in the form of a "map" of JPI containing what we consider major elements (so, not the totality, but a structured display of examples of elements of JPI). This "map" is based on long conversations which the authors have had at several occasions, particularly the second author's visits to Japan in 2013 and 2017; these conversations can best be characterized as the second author interviewing the first author, while the first author has also drawn on colleagues for some of the questions that arose. What we present here (in the next section) 
is just a rough synthesis of what we identified as important categories and examples during these conversations on JPI. It will also help to situate the two cases or "episodes" which are presented in the following sections, and in particular to explain the terms which we put in italics in the next paragraph, to indicate they have a precise meaning in JPI.

The two cases are:

- Episode 1, based on a video recording from a discussion at a meeting in a teachers, association seminar, and the abstract for a practice research report which was the subject of the discussion;

- Episode 2, based on a video recording from the presentation and discussion of the full paper at a regional conference for mathematics teachers.

The videos were transcribed, and the transcriptions and the documents were translated into English. We subsequently analysed the texts in terms of the mathematical and didactic praxeologies developed; we present the main outcomes of this analysis and their bearing on RQ2 after having outlined, for each episode, the overall structure of the document and the discussion.

\section{A rough map of Japanese Paradidactic Infrastructure}

While the case study will provide a deeper look into some segments of JPI, we first present an overall view of what we have come to consider the main elements of JPI. It is not a simple matter to provide a transparent and substantial structure to present this. A rather obvious dimension to include is the administrative levels to which the relevant institutions belong: local school, city (municipality), prefecture and national level. Indeed, Japanese mathematics teachers have opportunities to carry out their study and research at different levels (see, for the context of lesson study: Isoda et al. 2007; Lewis 2014; Lewis and Takahashi 2013; Murata and Takahashi 2002). Here, study and research are used in the sense of Chevallard (2006), who also explains how these activities relate to media (i.e. works which are made with the intention to instruct; for instance, a textbook, other teachers' publications) and milieus (i.e. an environment, such as an experimental class, which does not instruct about the questions investigated, but can, nevertheless, be used to carry out the investigation). Of course, the results of an investigation may give rise to formulating the results as media which may subsequently be studied by others.

We outline, in Table 1, the paradidactic infrastructure by major elements according to three categories that seem to structure it in a comprehensive way in terms of ATD. The first category is institutional frameworks that organize and provide the settings for teachers' activities. The second is these settings in which teachers' study and research are conducted; they may, in particular, support the use of specific forms of media and milieus, such as lesson plans and experimental lessons. The third category is the various types of media which are used or produced by teachers. Producing media such as papers for conference proceedings or journals, books for other teachers seems to be one of the most noticeable paradidactic practices of Japanese teachers, although it resembles in many ways the publishing practices of academic researchers. There are also evident differences, for instance teacher publications are usually not rigorously peer-reviewed.

We are not going to explain all the details of this table, but some of them. Most of the words used in the table are reasonably self-explanatory to give a correct impression of the activity. At the national level, the Ministry of Education designates and finances some 
Table 1 Elements of Japanese paradidactic infrastructure

\begin{tabular}{|c|c|c|c|}
\hline $\begin{array}{l}\text { Institutional } \\
\text { level }\end{array}$ & $\begin{array}{l}\text { Institutional } \\
\text { frameworks }\end{array}$ & Settings for teacher study and research & $\begin{array}{l}\text { Media used or produced } \\
\text { by teachers }\end{array}$ \\
\hline National & $\begin{array}{l}\text { Ministry of } \\
\text { education } \\
\text { National } \\
\text { education centre } \\
\text { Academic } \\
\text { associations } \\
\text { (teachers, } \\
\text { researchers) } \\
\text { Associations of } \\
\text { math teachers } \\
\text { Educational } \\
\text { companies }\end{array}$ & $\begin{array}{l}\text { Conferences in designated school } \\
\text { (kenkyuk } \bar{o}, \text { particular fuzoku schools) } \\
\text { In-service training (lectures, } \\
\text { workshops) by education centre } \\
\text { Conferences by associations, } \\
\text { companies }\end{array}$ & $\begin{array}{l}\text { National curriculum with } \\
\text { guide } \\
\text { Textbooks, teachers' } \\
\text { guides } \\
\text { Journals of academic or } \\
\text { non-academic } \\
\text { associations } \\
\text { Conference proceedings } \\
\text { Commercial magazines } \\
\text { Books by associations, } \\
\text { particular schools, } \\
\text { famous teachers, etc. } \\
\text { School math dictionary }\end{array}$ \\
\hline $\begin{array}{l}\text { Prefecture } \\
\text { ("ken") or } \\
\text { group of } \\
\text { prefectures }\end{array}$ & $\begin{array}{l}\text { Education board } \\
\text { Prefectural } \\
\text { education } \\
\text { centres } \\
\text { University } \\
\text { "education } \\
\text { practice } \\
\text { research" centre } \\
\text { Associations of } \\
\text { math teachers }\end{array}$ & $\begin{array}{l}\text { Conference in designated school } \\
\text { (fuzoku, etc.) } \\
\text { Conferences, meetings by associations } \\
\text { In-service training (lectures, } \\
\text { workshops, open lessons) by } \\
\text { education board or centres, etc. }\end{array}$ & $\begin{array}{l}\text { Conference proceedings } \\
\text { Handouts for } \\
\text { presentation } \\
\text { Mathematics teacher } \\
\text { journals (mainly edited } \\
\text { by local university) } \\
\text { Practice research reports }\end{array}$ \\
\hline $\begin{array}{l}\text { City ("shi") or } \\
\text { group of cities }\end{array}$ & $\begin{array}{l}\text { Education board } \\
\text { Associations of } \\
\text { math teachers }\end{array}$ & $\begin{array}{l}\text { Conferences, seminars, } \\
\text { workshops, lectures, open lessons }\end{array}$ & $\begin{array}{l}\text { Conference proceedings } \\
\text { Handouts for seminars, } \\
\text { presentation, etc. } \\
\text { Practice research reports } \\
\text { Books by associations } \\
\text { Lesson plans }\end{array}$ \\
\hline Local school & $\begin{array}{l}\text { School } \\
\text { Mathematics } \\
\text { department } \\
\text { Mathematics } \\
\text { teacher }\end{array}$ & $\begin{array}{l}\text { School-based training (kōnaikenshī: } \\
\text { lectures, workshops, open lessons, } \\
\text { lesson study, seminars, etc.) } \\
\text { Personal practice research }\end{array}$ & $\begin{array}{l}\text { Practice research reports } \\
\text { Lesson plans }\end{array}$ \\
\hline
\end{tabular}

schools (kenkyūkō, literally research schools) to undertake development and experimentation of new teaching contents and methods that are deemed potentially influential in the future national curricula (see, for example, Lewis and Takahashi 2013). These schools provide a special setting of national conferences, where teachers from all over Japan can learn of cutting edge ideas for mathematics teaching. Another special kind of schools is fuzoku schools which are schools "attached" to a university in view of supporting teacher education (see e.g. Shimizu 2002; Elipane 2012; Lewis 2014). Such schools also play a leading role and offer various settings for teacher learning at national or regional level. And all schools provide various settings for training, study and research of their own teachers "within the school" (kōnaikenshü), among which lesson study and open lessons are frequent activities (see, for example, Fernandez and Yoshida 2004).

Other important institutions in JPI are teacher associations, such as associations for mathematics teachers at the various levels, from city level to national level (see, for 
example, Isoda et al. 2007; Lewis and Tsuchida 1997; Lewis 2014). These usually organize conferences or seminars, they publish proceedings and reports from these settings, and they may also publish a journal. The teachers participate in these activities for their continuous professional development on a voluntary basis, unlike the mandatory konnaikensh $\bar{u}$. It should be noted, however, that teachers who are active in the community of association often become a leading teacher of the area and may be recruited to work in a fuzoku school or to other important positions.

An important entry in any of these media is the practice report, which reports on results of teachers' study and research, for instance during lesson study or practice research, which produces as a result quite similar media. The practice report involves, in particular, a first part which gives a thorough discussion of the question addressed and the material developed for it - that is, the result of kyōzaikenkyu (teaching materials research, cf. also Fujii 2015), which can be seen as an important interface between the media used and the media produced, during practice research.

At each level, the elements of the three categories in Table 1 (institutions, settings, media) are closely related each other, but as we shall see in Episodes 1 and 2, there are also crucial relations across the levels. Different settings listed in the table may include different activities. Conferences at national, prefectural or city level usually include lectures by expert teachers or university professors, oral or poster presentations in which teachers report their results of practice research or lesson study and open lessons including postdiscussion. Some settings may also include workshops in which teachers work together to study teaching materials or their own practices. Teachers who present must produce a paper for the conference, mostly practice research reports, and these are disseminated through proceedings or as handouts to the participants.

The objective of each setting can be quite different, according to the institutional framework. For example, at the national level, some settings are organized to appropriately disseminate the national curriculum or other teaching contents and methods (e.g. Lewis and Takahashi 2013), others are set up to increase the dynamics of teachers' study and research, and some are for specific in-service training purposes.

We now turn to two concrete and related "episodes" of teacher work in two of the above settings, a city-level association meeting and a regional meeting. Before delving into the two episodes, we present an outline of the context and the data (documents and video transcriptions from the two meetings).

\section{Episode 1: presentation and discussion of practice research at association meeting}

Sigma-kai is a seminar for mathematics teachers, which has existed since around 1980, as one among other activities of the association for mathematics teachers in Joetsu City area in Niigata prefecture. The meetings take place monthly (around 8 times a year), in the evening. This is a kind of teachers' circle or research group (Lewis and Tsuchida 1997; Fernandez and Yoshida 2004, pp. 213-221) which is very common in any part of Japan. Participation is not limited to the members of the association (about 90 registered members), but is open to any teachers of elementary and lower secondary schools of the area and to pre-service teachers from university (undergraduate or graduate students). University teachers may also participate regularly or occasionally. It draws a dozen or so 
teachers for each meeting. Participants are not fixed but vary from one meeting to another. Regular participants are usually teachers who are particularly active in practice research.

Our first episode is a meeting of Sigma-kai held from 19:00 on Wednesday 31 July 2013. The young teacher Mr. Onozuka, who has about 7 years of experience in junior high school (grade 7-9), is scheduled to present a first draft document for a practice research on "Ideas for teaching equations so that students realize the joy of mathematical activities". This is the headline of the 1 page handout (Fig. 1) which also carries the subtitle "The practice of introducing linear equations in junior high school grade 1". Participants receive the handout at the meeting. After finishing the draft based on advice from the discussion, Mr. Onozuka submitted it as an abstract for a regional conference held in October 2013. We return to this in Episode 2; it suffices to note here that Mr. Onozuka also planned to conduct classroom experiments of his activity in September, in order to present a full paper with experimental results at the regional conference.

The document has two sections, which correspond to what usually appears at the beginning of reports on practice research: (1) Context and purpose of the study and (2) Brief outline of the study. In (1), the teacher explains the context of the study: the teaching of linear equations in grade 7 . He considers that his earlier teaching of equations was "teacher centered, with few chances for students to develop their thinking and skills to apply [equations]". The teacher notices this especially when working with more advanced subjects, simultaneous linear equations and quadratic equations in grade 8 and 9, due to students' inadequate understanding on the basic properties of equality and skills of solving linear equations. Therefore, he has been thinking about a lesson which could give students a chance to enjoy mathematical activities and think more deeply about linear equations. The reference to an aesthetic term such as "joy" in the heading is usual in Japan and reflects the Japanese national curriculum (MEXT 2008).

The main Sect. (2) then outlines his ideas for two classroom activities, but gives nothing like a detailed lesson plan. The first activity consists of three exercises, asking students to complete partially filled $3 \times 3$ magic squares (shown in the left bottom line of Fig. 1). Mr. Onozuka writes: "I expect that students use a linear equation without noticing in exercise 1 and 2" [the first two squares]. His main idea, though, is the second activity which contains three exercises on completing what he calls "magic circles". Unlike magic squares, these are not a common item in recreational mathematics, but they appear, for instance, in a widely used textbook for Japanese grade 7 , in the chapter on arithmetic with signed numbers (Tokyo Shoseki 2016, p. 43). The idea is similar to magic squares: the sum of the four numbers in the each circle must be the same. As can be seen from Fig. 1, the teacher proposes some examples which include negative numbers, "to use things the students have already learned". He "intends that students complete magic circles using mathematical thinking and applying the method of solving equations they perceptively acquired in the class [the previous activity on magic squares]". The document mainly presents the exercises and their purpose, but do not give details as to what the teacher should do, e.g. to prompt the use of equations. The novelty of his idea is the link to linear equations, not the object of "magic circles" themselves.

The whole meeting lasts about $2 \mathrm{~h}$, in which the presentation and discussion of $\mathrm{Mr}$. Onozuka's paper takes place in the second hour (another paper, by another teacher, was presented and discussed in the first hour). There are 11 participants: Mr. Onozuka (O), the chair of the meeting (C) and eight other teachers (T1-T8, mostly more experienced than $\mathrm{O}$ ). 


\section{方程式指遒における数学的活動の楽しさを実感する指導のエ夫}

\section{一中学校第 1 学年「 1 次方程式」の導入の実践より一}

新潟桇上越市立城北中学校 小野塚 充

\section{1 研究の趣旨}

私のこれまでの方程式指導を振り返ると、教師 主導の展開で、生徒の思考力や活用力を引き出す ことに乏しかった。そのため、生徒の等式の基本 性質や方程式の解き方についての理解も不十分 であり、連立方程式や 2 次方程式を解く上で、思 考力をはたらかせ、それらを活用する力を身に付 けさせることができなかったと感じている。

そこで中学 1 年生「 1 次方程式」の導入におい て、魔法陣を題材とした展開を構想した。数同士 の新たな性質や考え方を見いだそうとしたり、学 んだ数学を具体的な課題の解決に利用しようと したりすることで、「思考」の場面を意図的に設 定する展開を考えた。また、課題の試行錯誤や操 作などから、数学的活動の楽しさや良さが、主体 的に学びたいという意欲につながり、より良い解 決方法を探究していくことを期待した。以上の点 を踏まえ、1 次方程式における数学的活動を取り 入れた、思考力をはぐくむ指導の工夫を研究の主 眼とした。

\section{2 研究の概要 (案)}

(1) 研究の視点

(1)課題解決や数量間の性質を考える活動から、 等式の性質・方程式の解き方の本質に生徒が 気づき、理解する。

(2)数学的活動に重点を置いた学習活動で、生 徒が経験的に未知数を求めていけるような 教材構成を考える。

(2)授業の実際 (案)

\section{(1) $「 3 \times 3$ 魔方陣」の問題}

正方形のマスの中に 1 9 までの数字を入れて、䋖、模、 ななめのそれそれの和が 15 になるようにする。空槢に入 る数字を求めなさい。

ここでは、生徒の思考を促していくためにヒ ント数を変え、条件を変更していく。課題 1 、 2 では感覚的に 1 次方程式を使い、課題 3 で は 1 次方程式を用いて解くのではなく、与え られた条件や、課題 1，2 から法則性を考え、 答えにたどり着くことを期待する。前者 $2 つ$ の課題から、1 次方程式の解き方を体感し、 解き方を学習する際の手がかりとさせたい。

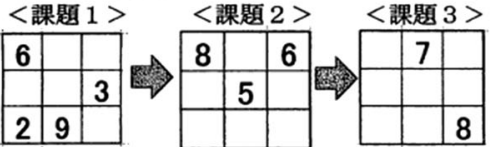

\section{(2)「円魔法陣」の問題}

図のように、3つの円を重ねてできる7つの部分に数字を 1つオ゙つ入れて、それぞれの円の中にある 4 つの数の和が ナへて等しくなるように、空相部分に入る数字を求めなさ w

<課題 $4>$ 「-4 て、円魔法陣を完成させよう」

次の学習課題では、円魔法陣を解いていく。 既習事項を活用するため、扱う数を自然数から 負の数まで拡張する。「 $3 \times 3$ 魔方陣」のように 和の指定がない中、試行錯誤しながら条件に合 うように推論しながら数字を入れていくことを 構想した。
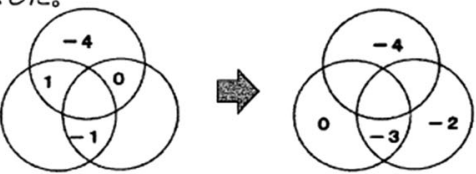

く課題 5 >「中央の数を 0 にして、4つの数の和 を考えながら円魔法陣を完成させよう」

円魔法陣の性質を理解し、 それぞれの円の中に入る数字 を追求していく。使用する数 もー 4 から 2 までである。こ こでの数学的活動は、「 $3 \times 3$ 魔法陣」と「課題 4 」で行っ た活動から類推し展開される ことを意図した。

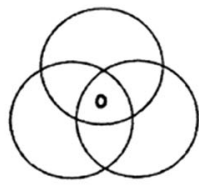

＜課題 $6>$ 「中央の数をいろいろ変えて、円魔法 陣を完成させよう」

最後の課題は、使用する 7 つの整数は変わらないが、 様々な解答を導くことを期待 する。「円魔法陣」は「 $3 \times 3$ 魔法陳」と異なり、何通りも 作ることができる課題である。

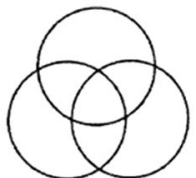
そのため数学的な思考や、その時間に体感的に 得た方程式の解き方の性質を活用し、魔法陣の 完成を目指すことをねらった。

できたものをみんなで共有し、新たな問題と してお互いに解きあうような時間設定をするこ とで、多くの生徒が充実感を味わいながら課題 に取り組めると考える。

Fig. 1 Handout for Sigma-kai meeting

O's initial presentation lasts for $12 \mathrm{~min}$, mainly outlining the above ideas; it is noticeable that he does not say anything about the possible links between the second activity (magic circles) and equations. He mentions, in particular, that he has tested the first 
activity (magic squares) with a small group of 8th graders, and they solved it easily by trial and error. He finally asks for advice:

O I am not sure if I can make a full lesson with these activities (...) I teach two first year [grade 7] classes, so I am thinking whether it will be better for the practice research to teach the classes in the same way, or in different ways for comparing the results. I'm planning to teach the lesson in September and make sure what to do for the presentation in October [at the regional congress, cf. above and Episode 2]. I want your advice before that. That's all, thank you

Already the very first comment brings up the question of how to establish the link between the two activities, and (linear) equations. The participants seem to agree that students will not think of, let alone explicitly use, equations in any of them. They also question the relevance of magic squares in this context and at this level, since they are often used in primary school where students find solutions without using any algebra. Then, a discussion follows on the second activity (exercise 4, corresponding to the two partially filled "magic circles" in the upper right column of Fig. 1):

T2 You need to show [the students] the merit of using equations

C Exercise 4 [first exercise in the second activity] means ... linear equations with two unknowns?

T2 As for exercise 4, you first put $a, b$ and $c$. (...) I think it's a little bit difficult, I mean, uh I see, it won't be simultaneous equations

O Yes, it will be linear equations with two unknowns

T2 And $x$ disappears instantly?

O Yes

Here, as nothing is written on the blackboard, the use of letters is not so precise, but it transpires from the following dialogue that several participants have already worked out how to solve the two parts of exercise 4 using (simultaneous) linear equations and in particular that the number corresponding to the "middle" number disappear in all of them and can thus be chosen freely. But the main didactic question of the link to equations, which students may be able to find, remains:

T7 We know it's better to use letters [equations] but [for students] it's the very beginning, isn't it?

$\mathrm{O}$ Yes

T7 I don't know whether students can think like that. I know they can if we tell them to

T2 Certainly, if we tell them to

The participants discuss the more general question of creating situations which students can model using equations. They agree that some work with equations is needed before there is any hope for students to be able to model the problem in exercise 4 by equations and also that this will be quite difficult to realize in grade 7 . Several teachers suggest other, less demanding, situations in which students can experience the use of equations. In particular T3 goes to the blackboard (scene from video shown in Fig. 2) to explain the idea of "Calculation Square" which he has seen "somewhere" and also tried out himself in the later parts of the lesson sequence on equations, where it is common to focus on applications: 


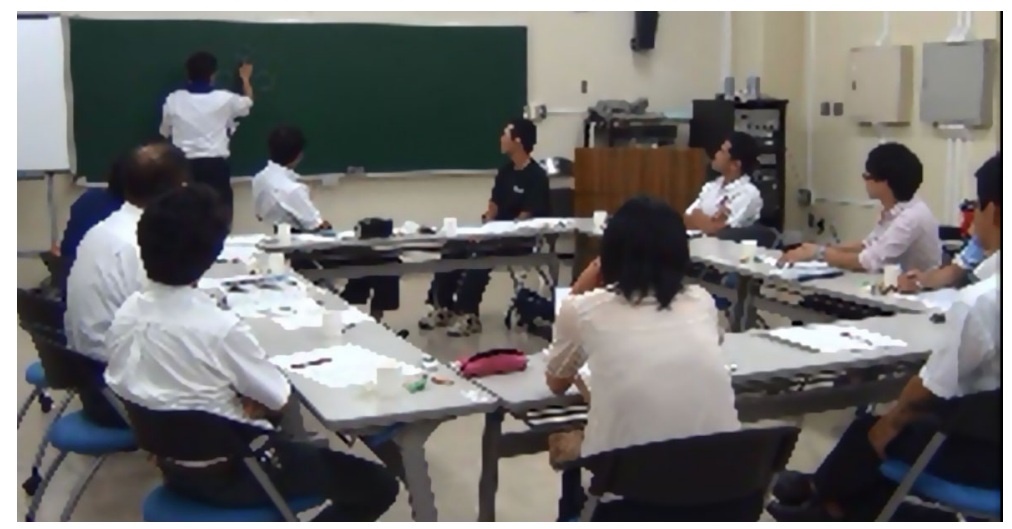

Fig. 2 Sigma-kai meeting
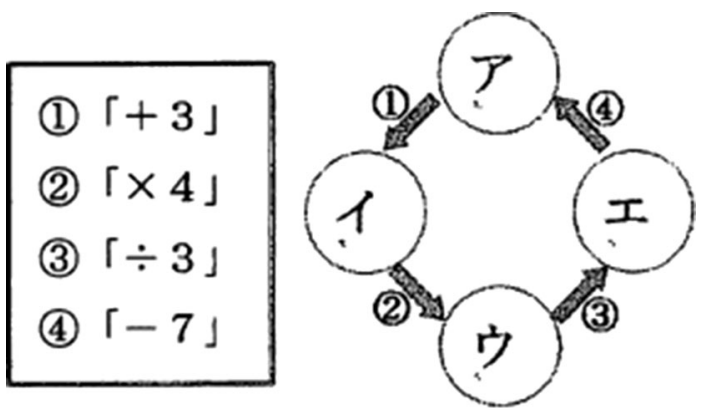

Fig. 3 A calculation square

T3 It's an exercise like you put any number on $\boldsymbol{\jmath}$, whatever you like, and calculate like this $(. .$.$) and then they try to use letters and make an expression$

T3 draws the diagram in Fig. 3 on the blackboard (here ア, イ, ウ, エ are the first characters in the Japanese sign system katakana, and $\ulcorner$ and $\lrcorner$ are brackets in Japanese language). The meaning of the arrows is that the operation indicated by the number next to the arrow should be carried out to get from one number to the next-for instance $ア+3=$ イ. The point is that one should return back to the same number when going round in the square. Students will initially not use algebraic expressions, but use trial and error; eventually, they should learn to write down an equation with $x$ in place of one of the unknown numbers, for instance letting $x$ replace $>$ leads to the equation: $4(x+3) /$ $3-7=x$. From this the unique solution can be found, and students will see how much easier that method is than trial and error. After discussing various potentials and challenges with this new idea, the teachers return to the activities of $\mathrm{O}$, and in particular the last part of the second activity. O proposes to ask students to create magic circles with no previously given numbers (last diagram in Fig. 1). A teacher (T1) explains a way to create magic circles with any given set of 5 integers, and how according to him, the work with this problem will have two phases: first to realize that the middle number can be chosen independently of the rest, and then to see that 4 other numbers (three in the intersections, 
and one more which is in just one of the circles) can be chosen arbitrarily, after which the remaining two will be determined.

After discussing a few more ideas, they turn to the revision of O's abstract:

C We should remember the deadline on the 5th [of August, 5 days later] (...)

C But if you carry out a good kyōzaikenky $\bar{u}$, the teaching practice will have no problem. (...) As T8 told you, if you may conceive a concrete task design, you will see where to land on.

O I am not confident if I can safely land in five days. There is some possibility of crashing.

T7 But you got a lot of hints.

At the end, the participants provide various advice on how to revise the paper, including erasing the subtitle (mentioned above), and also a few more suggestions on how to prepare the actual lesson or lessons to be experimented in September and reported on at the regional meeting in October. For instance, T2 suggests realizing different activities in the two classes of $\mathrm{O}$ in order to compare the results. Finally, $\mathrm{C}$ reminds $\mathrm{O}$ of one main outcome of the discussion:

C You have to sincerely think about the merits of equations which these activities bring out. Otherwise, your practice results in nothing

\section{Analysis of Episode 1}

The didactic praxis, which O's initial proposal concerns, is “the practice of introducing linear equations in junior high school grade 1" (citing the subtitle of the handout in Fig. 1). As a background for our analysis of this (and the next) episode, we need to first provide a brief analysis of the Japanese curriculum for this grade. The topic of linear equations comes after periods of work with "using letters" to express, for instance, number patterns, like $\frac{1}{2} n(n+1)$ as an expression for the general triangle number. It comprises, according to the ministerial guidelines:

(a) To understand the necessity and meaning of equations, as well as the meanings of letters within equations and their solutions. (b) To know how to solve equations based on the properties of equalities. (c) To solve simple linear equations with one unknown and make use of the linear equations in concrete situations. (MEXT 2008, p. 59)

Here, the first part of (c) clearly refers to praxis with types of task such as $T_{S \text { : }}$ solve $a x+b=c x+d$ for given values of $a, b, c$ and $d$, while (b) and most of (a) indicate the mathematical theory behind the techniques and their description. The second part of (c) refers to tasks of the type $T_{M}$ : "given (the description of) a situation, set up a linear equation as a model of that situation". The first part of (a) indicates elements of a didactic theory about the teaching of equations, where, in particular, the necessity of equations is strongly related to the second part of (c), as the idea is to present students with situations in which some problem can be easily solved by setting up an equation. It can be considered as 
a didactic justification (at the theory level) for including the praxis around $T_{M}$. The guidelines do not give other examples for this than simple problems involving proportions.

To teach this topic thus includes a number of didactic tasks, including that of having students work with situations which can show them the necessity of equations for solving problems. At the time of the meeting in Sigma-kai, O has not yet developed a complete lesson plan (which, in Japan, does not simply represent didactic techniques and technology, but also theoretical considerations). What he proposes is more basic: two types of mathematical tasks, namely completing magic squares $\left(T_{m s}\right)$ and circles $\left(T_{m c}\right)$. We note that the crucial importance of task design in Japanese teachers' practice research, which the following discussion exemplifies, was also emphasized by Fujii (2015), who situates task design in the wider context of kyōzaikenkyū (study of teaching materials).

A central element of the discussion of the teachers concerns the link between $T_{m s}$ and $T_{m c}$ on the one hand, and $T_{M}$ on the other. At the level of mathematical praxeologies, a link can certainly be established (this was also briefly alluded to in the discussion), but the main question from a didactic point of view is whether the activity can help showing students "the merit of using equations" (T2, quoted above). And the main quandary is that "we know it's better to use letters", but students don't, while "they can if we tell them to" (T7 quoted above). In particular, one teacher expresses a strong scepticism regarding the students subsuming $T_{m s}$ under $T_{M}$, as most students are familiar with the former since the early grades of elementary school. Then, T3 presents an alternative type of task, $T_{c s}$ (finding the numbers in a "calculation square", cf. Fig. 3). We notice that T3 indicates having learned about $T_{c s}$ "somewhere"- the source could be in any of the media and sites listed in Table 1, just as we can only speculate that $O$ has been inspired to propose $T_{m c}$ as a possible subtype of $T_{M}$ from having seen the former in a textbook. Unlike university researchers, teachers do not have a strong code for referencing sources; this relative lack of reference practice makes it difficult to track the various exchanges of knowledge which occur in JPI.

In fact the core of the teachers' discussion bears on whether and how the above ideas $\left(T_{m s}, T_{m c}, T_{c s}\right.$ ) could be seen, by students, as tasks of type $T_{M}$, and thus contributes to the realization of the curricular goals (a) and (c). This depends on didactic practice, and in particular on other didactic techniques than the mere choice of an exercise; the teachers seem to agree that the activities will have to be placed later in the sequence of equations, and not in the beginning, but also other details of the lesson itself will have to be fixed. $\mathrm{O}$ will have to decide on these before his lesson experiences in September, and in particular on how (and if) didactic techniques could support the links between the mathematical tasks he has presented in the handout, and $T_{M}$.

\section{Episode 2: presentation and publication of practice research}

On Friday October 25, Mr. Onozuka (O) participates in a regional conference for teachers from 4 prefectures around Niigata (about 500 participants in total from elementary to secondary levels). The 1 page abstract submitted to the conference (Fig. 1 with corrections based on the discussion in Episode 1) and published in the proceedings (Onozuka 2013) has now been extended to a 6-page "teaching practice report", which is distributed to the participants in O's presentation.

The paper (first page shown in Fig. 4) consists of the following sections: (1) Context and purpose of the study, (2) Main ideas of the study, (3) Content and method of the study, (4) Teaching plan of the unit, (5) Results and discussion and (6) Conclusion and future issues. One evident difference from the short paper presented at Sigma-kai is that it now presents detailed teaching 


\section{方程式指筫における数学的活動の楽しさを実感する指導のエ夫}

新潟県上越市立城北中学校 小野塚 充

\section{1 研究の趣旨}

私のこれまでの方程式指導を振り返ると、教師主導の展開で、生徒の思考力や活用力を引き出 すことに乏しかった。そのため、生徒の等式の基本性質や方程式の解き方についての理解も不十 分であり、連立方程式や 2 次方程式を解く上で、思考力をはたらかせ、それらを活用する力を身 に付けさせることができなかったと感じている。

そこで中学 1 年生「 1 次方程式」の単元において、生徒の思考力を促す教材を用いた展開を構 想した。数同士の新たな性質や考え方を見いだそうとしたり、学んだ数学を具体的な課題の解決 に利用しょうとしたりすることで、「思考」の場面を意図的に設定する展開を考えた。ここでの「思 考」とは、既習事項や知的直観などを基に、問題解決に向けて筋道や方法などを模索することと 私は考える。また、課題の試行錯誤や操作などから、数学的活動の楽しさや良さが、主体的に学 びたいという意欲につながり、より良い解決方法を探究していくことを期待した。以上の点を踏 まえ、1 次方程式における数学的活動を取り入れた、思考力をはぐくむ指導の工夫を研究の主眼 とした。

\section{2 研究の視点}

本実践は、 1 年生の方程式指導の場面において、「計算四角形」と「円魔方陣」という題材が生 徒の学習意欲を高め、問題解决における思考力や活用力を向上させることに有効かどうかを研究 したものである。 2 つの題材と以下の 2 点を研究の視点とし、授業展開を楆想した。なお、計算 四角形は 1 年 $\mathrm{A}$ 組 (40人)、円魔方陣は 1 年B組 (40人) で授業実践を行った。

(1) 課題解決や数量間の性質を考える活動から、等式の性質・方程式の解き方の本質に生徒が気 ゔき、理解する。

(2) 数学的活動に重点を置き、生徒に成り立つ事柄を予想させる活動の中で、方程式を用いるこ との良さを実感できるような教材構成を考える。

3 研究の内容と方法

○計算四角形を用いた 1 次方程式への導入

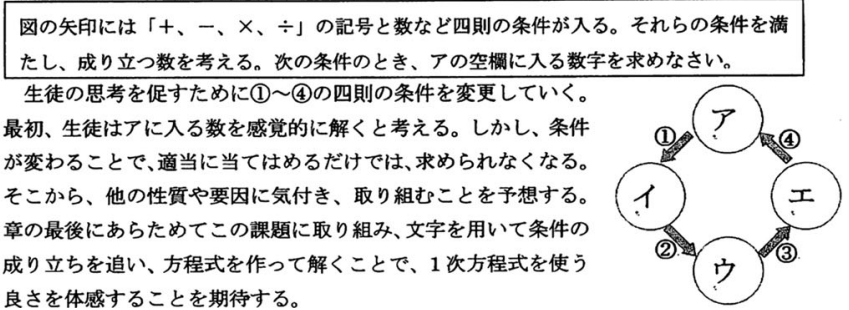

Fig. 4 First page of full paper for regional conference

plans of a sequence of lessons for linear equations, as well as results from experimentation in two classes (grade 7). But another important change has also occurred: the initial activity with magic squares has disappeared, and instead appears an activity on "calculation squares", as suggested by one of the participants (T3) in Episode 1. O has tried out these activities in a first 2-h lesson at the beginning of the 20-h sequence of lessons on equations. For comparison, he used different activities in the two classes, as suggested by $\mathrm{T} 2$ in Episode 1: calculation squares in one class and magic circles in the other. In both classes, he returned to the initial activity later in the sequence to try to let students use equations on it. This worked well in the class where "calculation squares" were used, but not in the other class. Quoting from the paper:

In the class where I introduced the calculation square, after teaching how to solve the linear equation, I asked students to solve the same task with equations. Then they were surprised to see how easily they can solve a problem by using equations. I think 
they could see how good and useful equations are. In the class where I introduced magic circles, in the same way, I also proposed the same task again. But there were too many letters they had to deal with, and they were sincerely trying to solve it, but it was not enough for them to understand. I felt the need for improving this task and studying how to use it in the class to make them realize how useful equations are.

At the conference, O presents his paper in about $18 \mathrm{~min}$, followed by 12-min discussion. Questions are invited from participants first, and then a reactor (somewhat like what the literature calls a "knowledgeable other") give some concluding comments. The first question asks a more detailed explanation on the difference between the class with calculation squares and the class with magic circles. The second question raised by a participant (P2) is, much as the discussion at the Sigma-kai meeting, on the link between magic circles and equation solving, but $\mathrm{O}$ has a more precise answer this time:

P2 This is a simple question, but how do you connect the magic circle with equations?

$\mathrm{O}$ After they studied equations, I asked the students to make equations in class ... [draws on the blackboard the magic circle with three empty fields shown in Fig. 5] As there are three numbers we don't know, I asked them if we can use the same letter or not. Then they said "No, because different numbers should be there" and wrote $x, y$ and $z$. [writes these on the figure]. And I asked them if we could make algebraic expressions and connect them by equal signs, then as the sums should be equal, they sum up to get [writes again] $x-3$ in this circle, and the lower right circle is $x+z-1$, and another is $x+y$. And they said these will be connected each other by equal signs, and I asked them to write on the blackboard. Then, they connected like this [writes equal signs vertically between $x-3, x+z-1, x+y$ ]. At this moment, some student realized and said that $y$ is equal to -3 . They found that there is no need to use the part $x$. In working on the magic circle, they noticed that they don't need $x$, they got $y$, and $y$ is equal to -3 , so one may put here -3 , then (...) Concerning the one of the very beginning, it's not really a linear equation, but students could work on this task by applying their knowledge on equations. However, to be honest, with the next task [corresponding to lower circle diagram to the right in Fig. 5], it did not go well as I had expected. Do I answer your question?
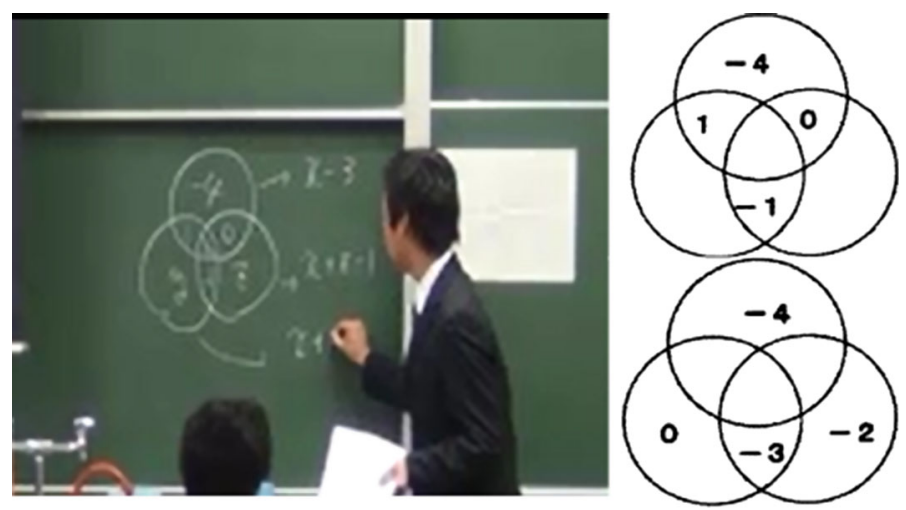

Fig. 5 Mr. Onozuka at the regional conference (left), explaining how to model the magic circle (upper figure to the right), using equations 
P2 Maybe the point is the next task, how it relates or not to the equations, to the introduction of equations. I couldn't see well and I'm wondering

O I couldn't see either

The chair then asks the reactor $(\mathrm{R})$ to give his comments. $\mathrm{R}$ explains the importance of developing activities which show students the usefulness of equations, and goes on to develop, on the blackboard (Fig. 6) how a magic circle in principle gives rise to two equations with 7 unknowns which can be reduced to 6 :

$\mathrm{R}$ I thought about it. [writes $a, b, c, \ldots$ in the Magic Circle on the blackboard] If I put letters like this, then in this magic circle, since the sums are equal ... [writes $a+d+g+$ $f=b+e+g+d=c+f+g+e$ on the board]. (...) We divide it into two ..., then, well, about the properties of equality, the teacher may ask "is there anything you may find about these two equations?"

He discusses briefly whether children could make these or other observations on such equations. R then points out that "magic circles" are normally used to work with arithmetic of integers (including negative numbers; see, for example, Tokyo Shoseki 2016, p. 43). At the end, as $\mathrm{R}$ is member of the education board of Joetsu City, he announces another conference for mathematics teachers taking place there.

\section{Analysis of Episode 2}

The outcome of the teaching practice, as described in the full paper and presented at the conference, is quite clear: after working with linear equations for some time, students can engage in solving tasks of type $T_{c s}$ by equation solving (schematically, the sequence $T_{c s} \rightarrow$ $T_{M} \rightarrow T_{S}$ ), and they even appreciate the facility which these techniques supply for $T_{c s}$, compared to the various guessing strategies they had deployed in the introductory activity. This justifies the didactic praxis empirically, in view of the official didactic theory according to which the teaching of this topic should show students the "necessity" or "merit" of linear equations as a means to solve problems.

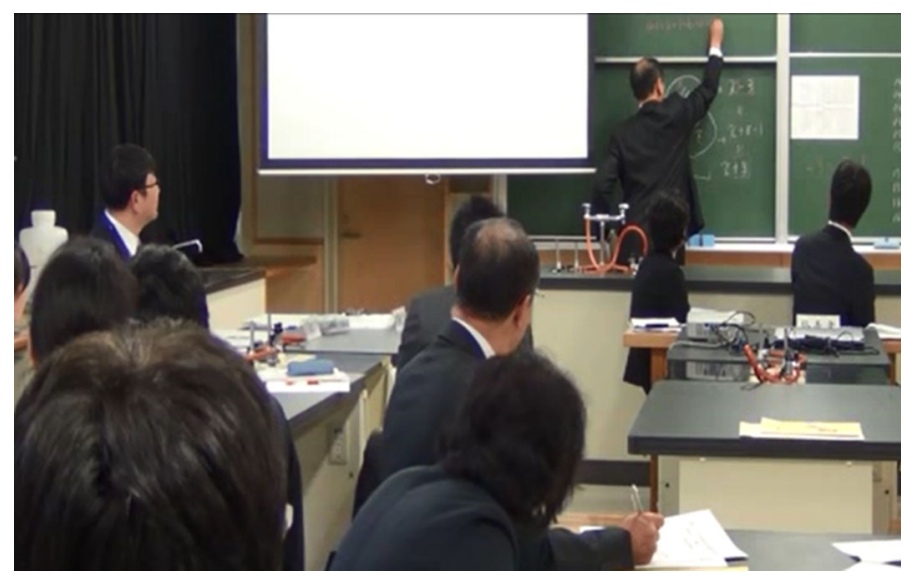

Fig. 6 The reactor explores the algebra of magic circles further 
By contrast, with the two tasks of type $T_{m c}$, a similar sequence does not work well even after students have been taught the basics of linear equations. In fact, students were able to set up equations for these problems (using techniques related to $T_{M}$ ), even if these equations get more than one variable, but they could not solve the equations, especially in the second exercise (lower right diagram in Fig. 5). In the long explanation of O quoted above, he explains that for the first exercise, the students got the equations

$$
x-3=x+z-1=x+y,
$$

and some students realized (probably looking at the first and last part of the above, and eliminating $x$ ) that $y=-3$. Notice that even if given the equation $x-3=x+y$ directly, this is a task which is not of type $T_{S}$, but some of the students could still solve it using similar techniques (here, strategic use of a specific "property of the equality sign" cited in MEXT 2008, p. 60: $a=b \Rightarrow a-c=a-c$ ). However, the students could not solve the equations resulting from the second exercise

$$
x+y+z-4=x+y-3=x+z-5
$$

which is in itself an interesting observation regarding how far students at this level can extend the techniques known from $T_{S}$ (and explicitly based on properties of the equalities) beyond the, by now, familiar context. For instance, looking just at the first equation, there are two added complications: that one has to "see" an expression $(x+y)$, not just a letter, which can be subtracted on both sides, and that an addition of 4 on both sides is also needed to get the value of $z$. Certainly, these extensions of techniques to new types of tasks will be highly relevant in grade 8 (for the study of systems of linear equations). In his initial presentation, $\mathrm{O}$ actually mentions this point:

$\mathrm{O}$ the textbooks have been revised, so that they have to learn this new kind of simultaneous equation, $A=B=C \ldots$ [in grade 8], but in this phase [of grade 7] the students find it difficult to use letters and work on this form of equations...

Mathematically, one can thus say that the activities based on $T_{m c}$ could furnish a bridge between the theme of linear equations and simultaneous equations. However, from a didactic viewpoint, the activity was only partly satisfactory, as just some students could solve the easier of the equations. This does not exclude that simpler tasks of type $T_{m c}$ could be more successful - for instance with more, or different, given numbers-or a different organization of the sequence (or of the particular lessons where the magic circles appear). But this is speculation: $\mathrm{P} 2$ and $\mathrm{O}$ conclude that it is not clear, from the experiment, whether $T_{m c}$ is didactically relevant for the grade 7 introduction of the praxeologies corresponding to $T_{S}$ and $T_{M}$. On the other hand, a clear result from the experiment seems to be that $T_{C S}$ is.

A final comment on the mathematical praxeologies at stake: the reactors' comment at the end concerns not only a more evident place of $T_{m c}$, but also (and before that) gives a hint on how equations might be used to provide a theory level of the corresponding mathematical praxeology. His general algebraic representation of "magic circles" simplifies readily to

$$
\left\{\begin{array}{l}
a+f=b+e \\
c+f=b+d
\end{array}\right.
$$

where $a, b, \ldots, f$ are six different integers. Note here that, as observed by the teachers in Episode 1, the "middle number" of the magic circle can be chosen freely and independently of the other six and can be entirely disregarded. Thus, given six integers, these 
relations can be used to find all magic circles that can be made with them (if any at all); fewer, naturally, if some of them are given. These and other aspects of the mathematics related to $T_{m c}$ are indeed at the horizon of the final comment, and there is no doubt that part of the fascination of $\mathrm{O}$ with $T_{m c}$ comes from having thought quite a lot about these objects, which he qualifies as "beautiful" and "curious" in his initial presentation at the meeting.

\section{Discussion and perspectives}

A first and partial answer to RQ1 is presented in Table 1. With the two episodes we have a more detailed view of the kind of didactic and mathematical praxeologies which can be presented and accessed within JPI (of course, based on some parts of it). At first, a sketchy proposal for a teaching experiment is presented by $\mathrm{O}$, in which the main elements is a didactic problem (the teaching of equations beyond teacher led drill) and where the preliminary answers consists essentially of two activities, with a mathematical type of task (completing magic circles) as the main new idea for the problem at hand. An alternative activity is proposed by one of the participants, who indicated he has heard of it "somewhere"-it could be, in fact, in most of the media cited in the right column of Table 1. He had also experienced it with success himself-as an element of didactic practice, it is thus not only backed by discursive reasoning but also by praxis. The link to the final experiment and report of $\mathrm{O}$ is clear: he has adopted the alternative and compares it with his own favourite (magic circles). The praxis is elaborated with didactic technology and theoretical perspectives in the full paper presented at the regional conference, where this didactic logos are not only shared but also further developed through a discussion of a mathematical (in fact algebraic) praxeology which supplies not only a technique to solve tasks of the type $T_{m c}$, but also a theory for this praxeology. $\mathrm{O}$ and his colleagues have advanced in getting to know the alternative $T_{c s}$, which despite its apparent existence in some media is certainly not widespread in Japan-but also in developing some first elements of mathematical and didactic logos about $T_{m c}$ and its links to equation solving. The first experiment of $\mathrm{O}$ did not succeed that well, but that is not going to stop him or others from continuing to work with this intriguing new idea. Eventually, it could perhaps become a central element in an innovative lesson which allows students to enjoy the mathematical activity, involving modelling and operating with equations.

We do not know the continuation of this particular set of episodes, which is also not the main point. The first point is that it shows the kind of work which lies behind the creative and student-oriented lessons which have attracted the interest of some Westerners who observed research lessons in Japan and which is undoubtedly a main motivating factor for their attempts to implement lesson study in their home country. In widespread accounts of lesson study, it is presented as an isolated and cyclic activity (e.g. Figure 1 in Lewis et al. 2006) in which the "planning" of a lesson is portrayed as a kind of group work, supported by the sheer study of textbooks. Possibly under the influence of such simplified operationalizations of lesson study, this will often be the situation when lesson study is implemented in other countries. By contrast, the two episodes contain none of the characteristics usually associated with lesson study: there is no full lesson plan, nobody observes O's experimental lessons, and his own observations are presented but not really discussed in the second of the two episodes. Nevertheless, the work that he has accomplished with colleagues in the two episodes, and alone when experimenting the two activities in his classes, could well lead him to eventually develop a lesson to be 
subsequently presented as an open lesson (Miyakawa and Winsløw 2013) or to be developed further in the course of a collective lesson study. Moreover, O's activities could be even considered as a part of lesson study in the Japanese sense. While the collective aspect of lesson study has been emphasized strongly in most of the English language literature, individual works are usually covered by the Japanese term, and one may in fact observe an individual-collective dialectic in Japanese lesson study (Miyakawa and Pepin 2016). Collective action may not be required in the actual lesson and subsequent discussion, but could still be present at other moments related to the lesson (as in the above episodes). In this way, the design of a creative and successful lesson often involves several elements of JPI and not just lesson study in the limited sense in which it is presented in parts of the literature.

In particular, venues for discussing more tentative ideas for mathematical activities, a variety of media beyond textbooks and curriculum guidelines, and systematic experimentation of hypotheses could be important sources of kyōzaikenky $\bar{u}$ ("study of teaching materials"). This term is, in some descriptions, reduced to a desktop activity to prepare a lesson, but an important component can in fact be discussion with other teachers of new materials produced by the teachers themselves, as we saw it in the two episodes. In both episodes, and the intermediate teaching experiment, we find, in fact a paradidactic practice which is certainly related to a didactic practice (that of teaching linear equations in grade 7) but which adopts, in many ways, the stance of a researcher: the didactic practice is not the final goal of the paradidactic practice, but it serves as an experiment from which articulate didactic knowledge (logos) is produced and subsequently shared with other teachers through the conference presentation and the proceedings paper. As in academic research, teachers' practice research may not always produce final answers; non-conclusive exploration of new ideas $\left(T_{m c} \rightarrow T_{M} \rightarrow T_{S}\right)$ and confirmation of others' informal results $\left(T_{c s} \rightarrow\right.$ $T_{M} \rightarrow T_{S}$ ) are also of value to advance the shared knowledge of the community. Moreover, it should be noted that (as for academic researchers) it is beneficial to a Japanese teachers' career to be active in presenting and publishing results of their research, through the variety of well-established channels, at different levels, which we listed in Table 1. It is also clear that the concerned elements of JPI depend on each other, in particular parts of the work done at the local association is motivated by the possibility of presenting a practice research report at the regional meeting; another possibility, closer to lesson study, is to present an open lesson there.

Another noteworthy feature of both episodes, which is also confirmed by our observation of similar sessions, for instance, at Sigma-kai, is that a central focus of the discussions are fine details of the mathematical praxeologies (in particular, the tasks) which they are considering to engage students with. Both $\mathrm{O}$ and some of the discussants, in particular $\mathrm{R}$ at the regional conference, show considerable and independent interest in the (to them) novel idea of modelling $T_{m s}$ and $T_{m c}$ using linear equations. Many studies of mathematics teacher practice have somehow expressed the idea of teachers doing mathematics themselves, as an element of their professional growth. For instance, Liping Ma (1999, p. 136) considered this as an important quality in Chinese teachers' paradidactic practice:

One thing is to study whom you are teaching, the other thing is to study the knowledge you are teaching. If you can interweave the two things together nicely, you will succeed. 
To create novel ideas for teaching a mathematical praxeology, one needs to create mathematical tasks with which students (in interaction with each other and the teacher) can generate the praxeology as such. Here, $T_{m c}$ appears to $\mathrm{O}$ as an intriguing concrete instance of the more abstract idea of enjoying a mathematical activity and modelling situations with linear equations $\left(T_{M}\right)$. To determine the first hypothesis for tasks to set to students (shown to the right in Fig. 5), he has of course experimented with various tasks and the techniques which could solve them, including algebraic ones. To determine the order of the two tasks - with the more difficult as the second one-he has probably developed the algebraic model outlined in our analysis of Episode 2, as a theoretical explanation of why this second task is significantly harder, even if one does not use algebra. His responses both at the Sigma-kai meeting and at the regional conference also suggest that he has been thinking of other tasks of type $T_{m c}$ as well as corresponding algebraic techniques, for instance to evaluate the number of solutions to a given task.

Finally, the two episodes illustrate our belief that JPI offers a tightly connected system for teachers' development and creation of shared didactic knowledge, and (in relation to this activity) also for maintaining a vital level of curiosity and "research" when it comes to the mathematical praxeologies they teach (and their "horizon", in the sense of Zaskis and Mamolo 2011). New ideas, such as using "calculation squares" or "magic circles" as a mathematical practice through which students may experience the merits of equations, can be circulated and tested more locally before, possibly, being more widely disseminated in practice research reports, teacher journals and books, textbooks, etc.; it also means that official curricula such as MEXT (2008) are not just implemented by teachers. The published nature of teachers' main achievements, in terms of building didactic praxeologies, means that they can function as an important resource for the periodic reforms of curricula. Together, Episodes 1 and 2 furnish an instance (and possible step) of how this bottom-up process may work, thanks to certain elements of JPI as illustrated in Table 1.

It is certainly relevant to ask how common practice research is in Japan, for instance how many teachers engage in publishing practice research reports. But it seems that there is no systematic data available. It must also be noted that the distinction between practice research and lesson study is not clear-cut. Practice reports do not only result from practice research to be presented in the meeting or conference, but also from lesson study; so almost all teachers of elementary and junior high school engage in writing such reports, at least for the lesson studies carried out as a part of kōnaikensh $\bar{u}$ (see Fernandez and Yoshida 2004, Ch. 13). Also, as mentioned earlier, particularly active teachers participate in association or circle meetings outside their school, and their work may have a broader audience. We do not have current figures, but some indications can be found. According to older statistics, almost half of the teachers take part in some activities of a local association (Kamiyama et al. 1983, cited in Fernandez and Yoshida 2004, p. 215), and around 80\% of school principals consider that their teachers attend professional activities outside of the school, according to a recent national survey (MEXT 2016, pp. 171, 176). In the case of Joetsu City, we note that there were around 90 registered members in the local association of elementary and junior high school mathematics teachers, out of several hundred such teachers in the city.

In conclusion, JPI endows the community of Japanese mathematics teachers with many of the characteristics which, according to Etzioni (cited in Chevallard 2009, p. 18), distinguishes a profession from a semi-profession. In particular, it is vital to help them build and share "a unique body of knowledge and skills", and its members are "characterized by a strong service motivation and lifetime commitment to competence" which they carry out within the framework of JPI, and within the didactic infrastructure of their school. Lesson 
study in all its varieties is certainly a remarkable element of JPI, but the whole system of institutions and media outlined in Table 1 is, we believe, crucial to account for its specific resources, results and impact in the Japanese context. This conclusion also indicates the importance of investigating paradidactic infrastructure in other countries. Indeed, paradidactic infrastructure is crucial to any initiative to develop the teaching profession.

Acknowledgement We would like to thank Mr. Mitsuru Onozuka who allowed us to collect data and use his materials. This project was partially supported by JSPS KAKENHI (26381185) to the first author and JSPS Bridge Fellowship (BR161601) grant to the second author.

Open Access This article is distributed under the terms of the Creative Commons Attribution 4.0 International License (http://creativecommons.org/licenses/by/4.0/), which permits unrestricted use, distribution, and reproduction in any medium, provided you give appropriate credit to the original author(s) and the source, provide a link to the Creative Commons license, and indicate if changes were made.

\section{References}

Blömeke, S., \& Delaney, S. (2012). Assessment of teacher knowledge across countries: A review of the state of research. ZDM Mathematics Education, 44(3), 223-247.

Chevallard, Y. (1999). L'analyse des pratiques enseignantes en théorie anthropologique du didactique. Recherches en Didactique des Mathématiques, 19(2), 221-266.

Chevallard, Y. (2006). Steps towards a new epistemology in mathematics education. In M. Bosch (Ed.), Proceedings of the $I V$ conference of the european society for research in mathematics education (pp. 21-30). Barcelona: Universitat Ramon Llull.

Chevallard, Y. (2009). Remarques sur la notion d'infrastructure didactique et sur le rôle des PER. Paper presented at the Journées Ampère in Lyon, May 2009. Retrieved from http://yves.chevallard.free.fr/ spip/spip/IMG/pdf/Infrastructure_didactique_PER.pdf.

de Lange, J. (2007). Large-scale assessment and mathematics education. In F. Lester (Ed.), Second handbook of research on mathematics teaching and learning (pp. 1111-1142). Charlotte: IAP.

Elipane, L. (2012). Infrastructures within the student teaching practicum that nurture elements of lesson study. In T.-Y. Tso (Ed.), Proceedings of the 36th conference of the international group for the psychology of mathematics education (Vol. 2, pp. 219-226). Taipei: PME.

Fernandez, C., \& Yoshida, M. (2004). Lesson study — A Japanese approach to improving mathematics teaching and learning. Mahwah: Lawrence Erlbaum.

Fujii, T. (2015). The critical role of task design in lesson study. In A. Watson \& M. Ohtani (Eds.), Task design in mathematics education. Switzerland: Springer.

Gueudet, G., Pepin, B., \& Trouche, L. (Eds.). (2012). From text to "lived" resources. Mathematics curriculum materials and teacher development. Berlin: Springer.

Gueudet, G., \& Trouche, L. (2009). Towards new documentation systems for mathematics teachers? Educational studies in mathematics, 71, 199-218.

Hiebert, J., Gallimore, R., \& Stigler, J. (2002). A knowledge base for the teaching profession: what would it look like and how can we get one? Educational Researcher, 31(5), 3-15.

Isoda, M., Stephens, M., Ohara, Y., \& Miyakawa, T. (Eds.). (2007). Japanese lesson study in mathematics: Its impact, diversity and potential for educational improvement. Singapore: World Scientific Publishing.

Kamiyama, E., Sakamato, H., Imazu, K., Sato, H., \& Sato, M. (1983). Kyōshoku nitaisuru kyōshi no taido (II) [Teachers' Attitude on Teaching Profession]. Bulletin of the Faculty of Education Mie University, $34,121-139$.

Knipping, C. (2003). Learning from comparing: a review and reflection on qualitative oriented comparisons of teaching and learning mathematics in different countries. Zentralblatt für Didaktik der Mathematik, 35(6), 282-293.

Leung, F. K. S., Graf, K.-D., \& López-Real, F. J. (Eds.). (2006). Mathematics education in different cultural traditions. The 13th ICMI Study. New York: Springer.

Lewis, C. (2014). How do Japanese teachers improve their Instruction? Synergies of Lesson Study at the School, District, and National levels. Board on Science Education Commissioned Paper. Retrieved from http://sites.nationalacademies.org/DBASSE/BOSE/DBASSE_084388. 
Lewis, C., Perry, R., \& Murata, A. (2006). How should research contribute to instructional improvement? The case of lesson study. Educational Researcher, 35(3), 3-14.

Lewis, C., \& Takahashi, A. (2013). Facilitating curriculum reforms through lesson study. International Journal for Lesson and Learning Studies, 2(3), 207-217.

Lewis, C., \& Tsuchida, I. (1997). Planned educational change in Japan: The case of elementary science instruction. Journal of Educational Policy, 12(5), 313-331.

Ma, L. (1999). Knowing and teaching elementary mathematics: Teachers' understanding of fundamental mathematics in China and the United States. Mahwah, N.J.: Lawrence Erlbaum Associates.

MEXT. (2008). Junior High School Teaching Guide for the Japanese Course of Study: Mathematics (Grade 7-9). Translated from Japanese by M. Isoda. Retrieved from http://www.criced.tsukuba.ac.jp/math/ apec/ICME12/Lesson_Study_set/Junior_high_school-teaching-guide-Mathmatics-EN.pdf.

MEXT. (2016). Heisei 28 nendo zenkoku gakuryoku gakushū jōkyō chōsa hōkokusho: shitsumonshi chōsa (Report of national assessment of learning progress 2016: questionnaire survey). NIER. Retrieved from http://www.nier.go.jp/16chousakekkahoukoku/report/question/.

Miyakawa, T., \& Pepin, B. (2016). Le "school-based" développement professionnel des enseignants en mathématiques: Deux pratiques collectives en Europe et au Japon. In Y. Matheron et al. (Eds.), Enjeux et débats en didactique des mathématiques (Vol. 1, pp. 145-177). Grenoble: La Pensée Sauvage.

Miyakawa, T., \& Winsløw, C. (2009). Didactical designs for students' proportional reasoning: An "open approach" lesson and a "fundamental situation". Educational Studies in Mathematics, 72(2), 199-218.

Miyakawa, T., \& Winsløw, C. (2013). Developing mathematics teacher knowledge: the paradidactic infrastructure of "open lesson" in Japan. Journal of Mathematics Teacher Education, 16, 185-209.

Murata, A., \& Takahashi, A. (2002). Vehicle to connect theory, research and practice: How teacher thinking changes in district-level lesson study in Japan. In D. L. Haury (Ed.), Proceedings of the 24th annual meeting of North American chapter of the international group of the psychology of mathematics education (pp. 1879-1888). Columbus, OH: PME-NA.

Onozuka, M. (2013). Ideas for teaching equations so that students realize the joy of mathematical activities. In Proceedings of 62nd congress on mathematics education of four Hokuriku Prefectures. Shimoniikawa, Toyama (in Japanese).

Rasmussen, K. (2016). Lesson study in prospective mathematics teacher education: didactic and paradidactic technology in the post-lesson reflection. Journal of Mathematics Teacher Education, 19(4), 301324.

Shimizu, Y. (2002). Sharing a new approach to teaching mathematics with the teachers from outside the school: The role of lesson study at 'Fuzoku'schools. Paper presented at the US-Japan cross cultural seminar on the professionalization of teachers through lesson study, Park City, UT, July 2002. Retrieved from http://www.lessonresearch.net/Yoshi.pdf.

Shoseki, Tokyo. (2016). Mathematics grade for junior high school grade 1. Tokyo: Tokyo Shoseki. (in Japanese).

Stigler, J., \& Hiebert, J. (1999). The teaching gap. New York: The Free Press.

Winsløw, C. (2011). A comparative perspective on teacher collaboration: The cases of lesson study in Japan and of multidisciplinary teaching in Denmark. In G. Gueudet, B. Pepin, \& L. Trouche (Eds.), From text to "lived" resources. Mathematics curriculum materials and teacher development (pp. 291-304). New York: Springer.

Zaskis, R., \& Mamolo, A. (2011). Reconceptualizing knowledge at the mathematical horizon. For the Learning of Mathematics, 31(2), 8-13. 